\title{
Time and Time Again
}

\author{
Brett Moule
}

On A stone bench in a small park, he glanced at his wrist. Time had stopped long ago, yet the cogs of his watch continued to turn, moving in circles back to the same place, over and over. His joints, too long at rest, moaned as he eased himself upwards with his cane. The day had begun again.

He left before the bell announced the end of another school day. He moved slowly past the fountain where he enjoyed his first kiss, exiting the park near the quaint church where he had been married. Continuing left, he ambled back up the quiet main street. A stooped, solitary figure.

He no longer crossed the road when he reached his old school. Young children in classrooms, old pupils in boardrooms; these days he was rarely recognised. He preferred it that way.

In his yard he set out creating neat little piles of gold, crimson and amber. The Tupelo revealing more and more of its russet branches. Spot fires of ruby-red foliage were gently reunited with their fallen brothers. His rhythmic and repetitive motions raking the close of day nearer.

Tins, packets, tins. He gazed resolutely into the belly of the pantry. Nothing. Dinner plans were gradually enveloped by a wistful haze. Drifting to the refrigerator he stared. The lonely milk bottle on its bare shelf. The refrigerator beeped, jolting him back. He resigned himself to cereal again.

He ate at the head of the table. He always had. It was the last familiar place in a house becoming all too unfamiliar. He turned his hearing aids down, listening to long forgotten arguments and the ghosts of laughter. He sat for a while. Eventually their echoes faded. The rinsed bowl was 
hidden away for another night. She would be disappointed in his dinner choice.

As the mist cleared, his reflection slowly surfaced. Fragile hands guided the razor down his softly creviced face, the skin slow to rebound after each downward stroke. The ashen strands of hair sparsely populating his scalp neatly aligned. Each ceramic tooth brushed ten times, no more, no less.

Dusty books lay dormant here and there. Still. Silent. So long his friends, they had become his enemy. The vapid crudity of television their substitute. The flickering images and distracting sounds safely cradled his thoughts, preventing the haze from returning. Pleasant at times, but never this late in the evening.

The ringing was distant to his numbed mind. His puffy hand softly pressed the handset to his ear. His deep, wary greeting softened immediately at the familiar voice. Eventually it came; the cancellation. He didn't blame them. It was a long way, especially for the children. Still, he went straight to bed that night, a full tablet instead of half.

Opening his eyes, the same kaleidoscope of colours greeted him after another dreamless night. Swirling around in his mind, he waited for their union. Thick glass lenses competed with the dense blur, focus eventually prevailing. Curtains drawn, he peered out at the sky. Cotton pants, flannel shirt, tweed jacket and cap. He laid his uniform on the bed.

Shower. Dress. Breakfast. He was ahead of schedule. He decided to go early today.

He stepped from the house, carefully packed lunch, cane and cushion his companions. The crisp air and silvery sunlight arrested his senses. The journey back took less time; his amble quickened. In the shade of the imported palm tree, he took his place on the stone bench. On his right, he lay his cane. He adjusted his cap and closed his eyes.

The school bell rang out the midday break.

She sat down at his side in the spot he had saved her. Unlike him, she had always loved sitting in the sun. Warm air and golden light caressed his face. He turned to her, tears rolling down his face, and breathed, 'I've missed you.'

The watch slowed gently until the cogs turned no more. Time had started again. 